Kong. Res. J. 4(1) : 8-9, 2017

ISSN 2349-2694

Kongunadu Arts and Science College, Coimbatore.

\title{
ECOLOGICAL CONNECTIVITY IN KINGSOLVER'S PRODIGAL SUMMER
}

\author{
Hema, C. \\ Department of English, NGM College, Pollachi. \\ Email : hemamphil28@gmail.com
}

\section{ABSTRACT}

Barbara Kingsolver has been acclaimed as an eco-friendly writer and her extensive education in biology is on display bin her book Prodigal Summer, laden with ecological concept and biological facts, weaving together three stories of human life. Each chapter in the novel Prodigal Summer deals with the three main characters and are named "Predators", "Moth Love", "Old Vhestnuts". In this novel the reader learns about animals, insects, forests, and the intertwining ecological system in which they coexist in the lush Appalachian Mountains or by living on a family farm in Kentucky. Even though humans are a different species than coyotes and moths and trees, feels Kingsolver, all deserve a place in the world since they depend on each other for different functions.

Keywords: Ecology, progeny, human interventions, rebirth, biological facts.

Barbara Kingsolver, born in 1955, grew up in a rural section of eastern Kentucky and began to write even as a young child. She took on a number of jobs such as copy editor, medical technician, researcher, and translator. Her experience at writing in the sciences at Arizona led her to a job writing features for magazines and newspapers, and she proved to be excellent at the work, winning an Arizona Press Club award, and an honorary Doctorate of Letters from DePauw. She began writing her own fiction during this period, usually at night. In 1985, she sat up at nights writing the book that would become The Bean Trees, a story about a woman who leaves her home in Kentucky for Tucson. In the next few years she published Homeland and Other Stories,Animal Dreams, and Pigs in Heaven. Her fourth novel, The Poisonwood Bible, appeared in 1998 and brought her true commercial success. The book was a bestseller for months and was an Oprah Book Club selection, guaranteeing it several hundred thousand sales. The story departed a bit from her previous work in that it focused on a missionary family in Africa and the subsequent effects of that experience on each member of the family.

Prodigal Summer appeared in October of 2000, and again won praise for the depth of its characters and the interwoven strands of three separate but related narratives. In 2002 Kingsolver published another book of essays, Small Wonder. A theme that seems to be developing in this book is a respect for and understanding of nature. The three main characters in this story spend much of their time studying and thinking about the nature that surrounds them. The author begins the book by giving detailed descriptions of the various flora and fauna that surround the characters during the rebirth and renewal taking place in an Appalachian mountain during spring season. Nature's call is audible throughout Kingsolver's world. In the opening pages she writes: "Here and now, spring heaved in its randy moment. Everywhere you looked, something was fighting for time, for light, the kiss of pollen, a connection of sperm and egg and another chance."(1) She then continues with the same amount of detail and analysis of the natural world throughout the rest of the seasonal cycle. The constant hum of the forest permeates every page of Barbara Kingsolver's novel, Prodigal Summer, with insects incessantly buzzing, twigs snapping, animals scurrying, leaves whispering, birds squalling, moths mating, it's as if hundreds of different languages are being spoken all at once. The forest is not a quiet place, and Prodigal Summer is not a quite novel.

The significance of the novel's title is the description of summer in the story is "prodigal" in related senses, which are explored in detail. The most obvious meaning is that of "wantonness or wastefulness or fecundity," and the natural world of Zebulon county certainly lives up to the definition. The summer is repeatedly described as being wet, lush, exuberant, extravagant, passionate, and alive. Life is everywhere, and new growth abounds in the woods and farms. Deanna notices this early in the season.

She needed to listen to this: prodigal summer, the season of extravagant procreation. It could wear out everything in its path with its passionate excesses, but nothing alive with wings or 
a heart or a seed curled into itself in the ground could resist welcoming it back when it came (51).

It is the return of life after the winter and the continual promise of regeneration. "In all her life Lusa had never seen such an oversexed, muggy summer. Just breathing was a torrid proposition" (223)

The three women protagonists have in common their independence - ranging from Deanna's unselfconsciousness to Lusa's faltering self-sufficiency - and an intuitive regard for nature, backed up by superior education. Kingsolver, a former biologist and journalist, has a rare ability to communicate widely what she knows as a scientist, and this novel sounds warnings against hunting predators who compensate by breeding faster, or against pesticides that boost pest populations by killing off the bugs that prey on them.

The ecosystem reestablishing itself in the protected forest is seen as a common habitat, not a wilderness to be kept at bay from the farmland. This is a novel that insists on the shared animality of humans, regardless of their efforts to subdue nature. That the world is a place with its own immutable rules of hunger and satisfaction, is clear in the novel's erotic undertow amid the spring fecundity of lavishly described woodlands, and in the characters' human desires, not only for sex, but to mark their territory, for progeny, even for food; disavowing any sentimental attachment to fluffy animals, Deanna relishes meat, saying "I know a little too much about animals to try to deny what I am". She is amazed by the obvious animal facts people refused to know about their kind, such as that women exposed to enough moonlight will ovulate at full moon, or that pheremones announce their periodic fertility to men. Smells, says Lusa, who sniffs her absent husband in strange men's work clothes, are "a whole world of love we don't discuss". In a pointed irony, assiduous sperm get the better of Eddie's impressive array of prophylactics. Although insistence on human biology has been used conservatively, to limit rather than liberate women, Kingsolver's view of nature is no endorsement of the nuclear family. Not only do her women glory in single motherhood, but like the packs of sister coyotes that nurture an alpha female's young, Lusa's sisters-in-law prepare to adopt the children of a sister who has cancer.

The Southern Appalachia, where Prodigal Summer takes place, has the greatest terrestrial biodiversity in the world. Calculated by using a mathematical formula called the Shannon Index, diversity takes into account the number of individuals of a certain species, the number of species in the test area, the total number of all the individuals in the species, and the relative abundance of each species. Diversity is important for ecosystems because it allows more interactions between species, like more complex food webs and better soil and water quality, since each species is doing its part.

For instance, the Carolina Parakeet, now extinct, used to specialize in eating cockleburs. But since there is no longer the 'eater' on that food web, the cockleburs have taken over Southern Appalachia, "uneaten and would continue so for the rest of time"(247). Just increasing the number of one species would not add to diversity. The addition of only a few members of several species is better than lots of justone species. Kingsolver tries to show us the importance of biodiversity through Deanna's love of the coyote. Though sheep farms are at risk economically if there are coyotes in the area, the biodiversity of the Appalachia may be restored through the addition of a top predator. This point is hammered into the reader over and over through Deanna's stream of consciousness. Yet the idea that species balance is essential to a healthy ecosystem is ultimately Kingsolver's idea, because her characters Lusa, Deanna, and Garnett work so hard to preserve species in the earth.

Each of the three main characters comes to a complicated understanding of nature that changes over the course of the book. Garnett seems to change most radically in this respect. His interactions with Nannie Rawley over the summer finally lead him to accept some of her explanations for her organic farming methods and distrust of pesticides. He initially wants the county to spray herbicide on the edges of the road near his farm, uses the poison Sevin in his fields, and believes that Nannie's refusal to do this is actually causing him harm. Her approach to nature involves working closely with natural processes, using natural remedies to farming problems, and avoiding drastic human interventions in the environment.

Prodigal Summer is a rich and compulsive read. Its acute and sensuous observation of the natural world reveals an unexpected beauty, as it traces human love in the flight of a luna moth.

\section{REFERENCE}

Kingsolver and Barbara, 2001. Prodigal Summer. New York: Harper Collins. 